\title{
Complex aphthosis-like pemphigus vulgaris during pregnancy
}

\author{
Gebelikte kompleks aftosis benzeri pemfigus vulgaris
}

๑ Sema Aytekin, ๑ Fatih Göktay, ๑ Șirin Yașar, ๑ Pembegül Güneș*

Haydarpașa Numune Training ang Research Hospital, Clinic of Dermatology; *Clinic of Pathology, İstanbul, Turkey

Keywords: Complex aphthosis, pemphigus, pregnancy

Anahtar Kelimeler: Kompleks aftosis, pemfigus, gebelik

\section{To the Editor,}

Pemphigus vulgaris (PV) is a rare immune-mediated blistering dermatosis which is uncommon during pregnancy and generally presents with unhealing, painful, oral erosions ${ }^{1-5}$. However, transient or aphthous-like lesions are rarely present in cases of PV and the condition may consequently be misdiagnosed as recurrent aphthous stomatitis (RAS) or Behçet's disease $(\mathrm{BD})^{2,3}$.

A 34-year-old female at 23 weeks' gestation presented with a 4-year history of RAS. She had previously been treated for RAS by means of oral hygiene practices, antiseptics, and topical corticosteroid, but her condition showed no improvement and she continued to experience multiple painful, recalcitrant, aphthous lesions. The patient had no history of erythema nodosum or arthralgia and her pathergy test was negative. Ophthalmological examination yielded normal results. Dermatological examination revealed multiple irregular aphthous lesions without erythematous haloes across the labial and buccal mucosa, and on the lateral borders and inferior surface of the tongue (Figure 1a). The patient also had a genital ulcer on the inner surface of the labia minor (Figure 1b). Histopathological examination of the oral lesions revealed acantholysis in the bottom of the stratum spinosum, with the stratum basale cells of the epidermis remaining attached to the basement membrane, prompting a diagnosis of PV. Direct immunofluorescence (DIF) revealed intercellular deposits of IgG and C3. Enzymelinked immunosorbent assay (ELISA) detected desmoglein-3 (Dsg3) and desmoglein-1 (Dsg1) at $>200,1.28 \mathrm{RU} \mathrm{mL}$. Indirect immunofluorescence (IIF) indicated increased cell surface antibody titers at 1:120. The patient was treated with intralesional triamcinolone acetonide and topical steroids. The genital ulcer healed without significant scarring (Figure 1c). The patient delivered a healthy infant via caesarean section and both mother and infant were healthy during the postnatal period. Approximately 6 months later, however, the patient's oral mucosal aphthous lesions and erosions returned. Prednisolone was administered at a dose of 1 $\mathrm{mg} / \mathrm{kg} /$ day and azathioprine at a dose of $2 \mathrm{mg} / \mathrm{kg} /$ day. The steroid treatment was gradually decreased and discontinued after 6 months. The azathioprine dosage was reduced and discontinued in the first year of treatment. Dsg3 levels vary between 126 and 200 in most patients. Some aphthous lesions healed within a short period without causing the

Yazıșma Adresi/Address for Correspondence: Sema Aytekin MD, Haydarpaşa Numune Training ang Research Hospital, Clinic of Dermatology, İstanbul, Turkey Tel.: +90 5332134959 E-posta: semaaytekin@yahoo.com Geliş Tarihi/Received: 03.02.2020 Kabul Tarihi/Accepted: 15.06.2020 ORCID: orcid.org/0000-0003-1376-1573

C) Copyright 2020 by Turkish Society of Dermatology and Venereology

Turkderm - Turkish Archives of Dermatology and Venereology published by Galenos Yayınevi. 


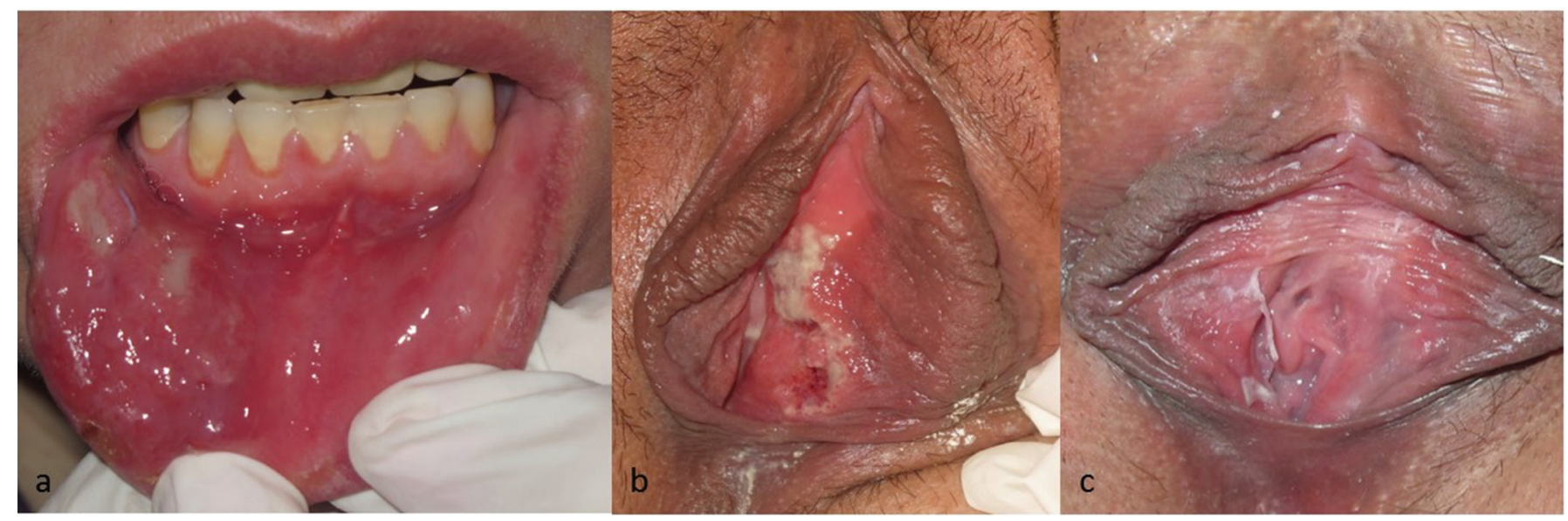

Figure 1. (a) Multiple irregular aphthous lesions without erythematous haloes across the labial mucosa, (b) genital ulcer on the inner surface of the labia minora, (c) healing without scarring

patient significant discomfort or resulting in erosions. She preferred to continue the follow-up without treatment.

RAS is a common disease of the oral mucosa, affecting around $20 \%$ of the world's population, with more women than men affected by the condition, which typically manifests within the first decade of life. PV is a rare autoimmune bullous disorder varying in incidence from 0.5 to 3.2 cases per 100,000 people per year ${ }^{4,5}$. In contrast to RAS, PV only rarely appears early in life. Pregnancy may precipitate or aggravate PV. Flareups are more frequently reported during the first and second trimester and in the postpartum period. Prednisolone, azathioprine, dapsone, intravenous immunoglobin, and plasmapheresis are all considered safe therapeutic options for managing PV during pregnancy, while topical steroids and intralesional steroid injection can be used in mild cases. Our patient was successfully treated with intralesional and topical steroids. Oral PV lesions may closely mimic aphthous lesions, particularly when they do not extend peripherally and when they heal without any treatment ${ }^{1-4}$. Although RAS is considered to be one of the major differential diagnoses of oral PV, the aphthous-like presentation of PV has received little emphasis in literature. Daneshpazhooh et al. ${ }^{3}$ found that of 185 pemphigus patients with histories of transient aphthous-like lesions, 95\% were misdiagnosed as having aphthae. This temporary nature of the lesions may account for the frequent misdiagnosis of aphthae or $\mathrm{RAS}^{3}$. BD is frequent in Turkey, therefore PV should be strongly considered for differential diagnosis of RAS especially in patients over middle aged ${ }^{6}$. DIF and IIF methods are important in the differential diagnosis of atypical RAS and vesiculobullous diseases. AntiDsg3 positivity alone does not indicate a diagnosis of PV since it may be non-pathogenic ${ }^{7}$. Additionally, genital aphthous ulcers often cause scarring, even mutilation or perforation, while pemphigus lesions do not leave scars 6 .

To conclude, PV should be borne in mind as a rare but possible differential diagnosis of aphthous stomatitis, particularly in cases of late onset in patients from predisposed racial groups.

Photograph consent was obtained from the patient.

\section{Ethics}

Informed Consent: Photograph consent was obtained from the patient.

Peer-review: Externally peer-reviewed.

\section{Authorship Contributions}

Surgical and Medical Practices: S.A., Concept: S.A., Design: S.A., Data Collection or Processing: S.A., F.G., Analysis or Interpretation: S.A., S..Y., P.G., Literature Search: S.A., Writing: S.A.

Conflict of Interest: No conflict of interest was declared by the authors.

Financial Disclosure: The authors declared that this study received no financial support.

\section{References}

1. Bialynicki-Birula R, Dmochowski M, Joanna Maj J, Gornowicz-Porowska J: Pregnancy-triggered maternal pemphigus vulgaris with persistent gingival lesions. Acta Dermatovenerol Croat 2011;19:170-5.

2. Femiano F, Gombos F, Nunziata M, Esposito V, Scully C: Pemphigus mimicking aphthous stomatitis. J Oral Pathol Med 2005;34:508-10.

3. Daneshpazhooh M, Chams-Davatchi C, Ramezani A, Moinedin F, Rezae Hemami M: Abortive aphthous-like oral lesions: an underreported initial presentation of pemphigus vulgaris. J Eur Acad Dermatol 2009;23:157-9.

4. Daneshpazhooh M, Chams-Davatchi C, Valikhani M, et al: Pemphigus and pregnancy: A 23-year experience. Indian J Dermatol Venereol Leprol 2011;77:534

5. Yayli S, Harman M, Baskan EB, et al: Epidemiology of Pemphigus in Turkey: One-year Prospective Study of 220 Cases. Acta Dermatovenerol Croat 2017;25:181-8.

6. Aytekin S, Yaşar \$̧, Göktay F, Atış G. Mutilating genital aphthous ulceration causing perforation in two women. Clin Exp Dermatol 2019;44:20-1.

7. Muramatsu K, Nishie W, Natsuga K, et al: Two cases of erosive oral lichen planus with autoantibodies to desmoglein 3. J Dermatol 2016;43:1350-3. 